Review Article

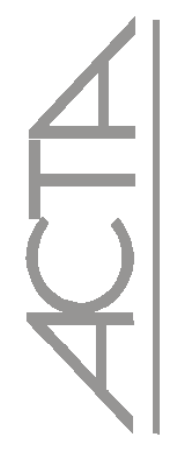

\title{
Spiritual dimension of children and adolescents with cancer: an integrative review*
}

\author{
Dimensão espiritual de crianças e adolescentes com câncer: revisão integrativa \\ Dimensión espiritual de niños y adolescentes con cáncer: revisión integrativa
}

\author{
Daniele Corcioli Mendes Espinha ${ }^{1}$, Regina Aparecida Garcia de Lima ${ }^{2}$
}

\begin{abstract}
Objective: To review scientific literature relating to the spiritual dimension of children and adolescents with cancer. Methods: We conducted an integrative literature review in the LILACS, SciELO, PsycINFO and MEDLINE databases in the period between 1990 to 2011. Results: Twenty-one studies were analyzed and grouped into thematic categories: quality of life and elements of spirituality; alternative and complementary therapies: spirituality as a therapeutic resource; spirituality as a coping strategy and spirituality as an attribute of existential transformations. It was found that spirituality is present at different stages of the disease experience and that its forms of expression may vary, according to age and cognitive development. Conclusion: There is a scarcity of specific scales for this age range and a need for scientific production relating to the spiritual dimension of children and adolescents with cancer. Descriptors: Neoplasms; Children; Adolescents; SpiritualityKeywords: Neoplasms; Child; Adolescent; Spirituality
\end{abstract}

\section{RESUMO}

Objetivo: Analisar a produção científica relativa à dimensão espiritual de crianças e adolescentes com câncer. Métodos Realizou-se uma revisão integrativa da literatura nas bases de dados LILACS, SciELO, PsycINFO e MEDLINE no período entre 1990 a 2011. Resultados: Vinte e um estudos foram analisados e agrupados nas categorias temáticas: qualidade de vida e os elementos da espiritualidade; terapias alternativas e complementares: a espiritualidade como recurso terapêutico; a espiritualidade como estratégia de enfrentamento e a espiritualidade como atributo das transformações existenciais. Identificou-se que a espiritualidade está presente nas diversas fases da experiência da doença e que suas formas de expressão podem variar, de acordo com a idade e desenvolvimento cognitivo. Conclusão: Observou-se escassez de escalas específicas à faixa etária e necessidade de produção científica relativa à dimensão espiritual de crianças e adolescentes com câncer.

Descritores: Neoplasias; Criança; Adolescente; Espiritualidade

\section{RESUMEN}

Objetivo: Analizar la producción científica relativa a la dimensión espiritual de niños y adolescentes con cáncer. Métodos: Se realizó una revisión integrativa de la literatura en las bases de datos LILACS, SciELO, PsycINFO y MEDLINE en el período comprendido entre 1990 al 2011. Resultados: Fueron analizados veintiún estudios y agrupados en las categorías temáticas: calidad de vida y los elementos de la espiritualidad; terapias alternativas y complementarias: la espiritualidad como recurso terapéutico; la espiritualidad como estrategia de enfrentamiento y la espiritualidad como atributo de las transformaciones existenciales. Se identificó que la espiritualidad está presente en las diversas fases de la experiencia de la enfermedad y que sus formas de expresión pueden variar, de acuerdo con la edad y el desarrollo cognitivo. Conclusión: Se observó escasez de escalas específicas al grupo etáreo y necesidad de producción científica relativa a la dimensión espiritual de niños y adolescentes con cáncer. Descriptores: Neoplasias; Niño; Adolescente; Espiritualidad

\footnotetext{
${ }^{1}$ Specialist in oncology nursing for the School of Nursing of Ribeirão Preto, University of São Paulo (Universidade de São Paulo - USP), Ribeirão Preto (SP), Brasil.

${ }^{2}$ Full Professor, School of Nursing of Ribeirão Preto, University of São Paulo (Universidade de São Paulo - USP), Ribeirão Preto (SP), Brasil.
} 


\section{INTRODUCTION}

The impact of the cancer diagnosis, its treatment and its implications, are experienced by patients and their relatives with pain and suffering, despite the many advances made by science in recent years to ensure cure and quality of life ${ }^{(1)}$. The suffering experienced by children and adolescents with cancer refers not only to physical pain, but to the context of the disease composed of biological, emotional, social, behavioral, existential and spiritual dimensions ${ }^{(2)}$.

With respect to this theme, the scientific production related to spiritual care in nursing practice has received special attention in recent decades, with studies seeking to refine the theoretical concepts and the importance of the association of spirituality to physical health ${ }^{(3)}$. By providing spiritual care, nurses can encounter barriers, such as lack of communication skills for the identification and discussion of spiritual issues, in addition to lack of knowledge about the topic ${ }^{(4)}$.

From the perspective of adding knowledge to this topic, this study had the objective of analyzing the scientific production relating to the spiritual dimension of children and adolescents with cancer, between 1990 and 2011.

\section{METHODS}

Aiming to achieve the proposed objectives, the following steps of the integrative review method were followed: definition of the problem, search for and selection of the articles, definition of the information to be extracted and their analysis, discussion and interpretation of the results, and synthesis of the knowledge obtained. To guide the review, the orienting question was: What is the scientific knowledge produced about the spiritual dimension of children and adolescents with cancer?

The key words were previously selected, extracted from the DeCS (Descritores em Ciências da Saúde) vocabulary, MESH version (Medical Subject Headings), using the following terms in various combinations: cancer; neoplasms; children; adolescent; spiritual; spirituality.

The following inclusion criteria were used: articles published in full text, whose theme dealt with aspects of the spiritual dimension of children and adolescents under 18 years of age, exclusively with cancer, including the ones reported by parents and / or other family members. Articles in English, Spanish and Portuguese, published from January 1990 to March 2011; with abstracts indexed in the Scientific Electronic Library Online (SciELO) and in electronic databases: Latin American and Caribbean Health Sciences (LILACS), American Psychological Association (PsycINFO), and
Medical Literature Analysis and Retrieval Sistem Online (MEDLINE); to search for articles on the latter, we chose to access PubMed (National Library of Medicine), allowing a more detailed selection of material.

At the intersection of the descriptors used for the search, we found 150 references. By means of an exhaustive reading of the titles and abstracts, the references selected resulted in 41 articles. These studies were examined based on the study objective and the inclusion criteria, with 21 articles being selected for analysis; and of these three were discarded because of repetition within the databases, so that 18 articles were analyzed, all available in the MEDLINE database. In order to complement the sample, we included three more articles that were obtained based on analysis of the references of the studies previously selected and through the routine reading of the primary author, the latter being the only article in the Portuguese language. Therefore, the final sample consisted of 21 articles.

For the analysis of the selected articles, we designed a script containing the following indicators: reference bibliography, the means by which the product was obtained, identification of the author, keywords adopted, population / subject investigated, principal theme, methodological approach / method, objective or question of the investigation, results found, and implications for nursing.

\section{RESULTS}

In this study, the 21 articles analyzed dealt with the spiritual dimension of children and adolescents with cancer. The data in Table 1 present the articles selected, according to the title, authors, year of publication, country of origin, method and principal results of the research.

The studies selected involved 72 authors, of whom the majority were nurses (34\%). Authors with doctoral degrees had the majority of the titles, with 21 representatives $(29 \%)$.

Regarding the stratification of the quality of the intellectual production (Qualis), the only national periodical that was included in the sample selection had the quality criteria of B3. The periodical that had the largest number of articles, having published six of the 21, was the Journal of Pediatric Oncology Nursing, with an impact factor of 1.029 .

From the analysis of the contents of the articles reviewed, four thematic categories emerged: quality of life and the elements of spirituality ${ }^{(8,14,19-20)}$; alternative and complementary therapies: spirituality as a therapeutic resource ${ }^{(6,9,13,16,23,25)}$; spirituality as a coping strategy ${ }^{(5,7,11,17,18,22,24)}$ and spirituality as an attribute of the existential transformations ${ }^{(10,12,15,21)}$. 
Table 1. Distribution of the selected articles, according to title, authors, year of publication, country of origin, method and principal results of the research (1990-2011)

\begin{tabular}{|c|c|c|c|c|}
\hline Title & Authors & $\begin{array}{l}\text { Year } \\
\text { (Country }\end{array}$ & $\begin{array}{l}\text { Type of } \\
\text { Study }\end{array}$ & Results \\
\hline $\begin{array}{l}\text { Spiritual care for children } \\
\text { with cancer }^{(5)}\end{array}$ & $\begin{array}{l}\text { Hart, } \\
\text { Schneider }\end{array}$ & $\begin{array}{l}1997 \\
\text { (USA) }\end{array}$ & $\begin{array}{l}\text { Literature } \\
\text { review }\end{array}$ & $\begin{array}{l}\text { Spiritual assistance activities make it possible for children with } \\
\text { cancer to find continuity in relationships, meaning and purpose } \\
\text { in life. }\end{array}$ \\
\hline $\begin{array}{l}\text { Use of alternative therapies } \\
\text { for children with cancer }{ }^{(6)}\end{array}$ & $\begin{array}{l}\text { Friedman } \\
\text { et al. }\end{array}$ & $\begin{array}{l}1997 \\
\text { (USA) }\end{array}$ & Transversal & $\begin{array}{l}\text { The use of alternative therapies is not limited to families of } \\
\text { children with cancer, being commonly used for children with } \\
\text { routine pediatric problems. }\end{array}$ \\
\hline $\begin{array}{l}\text { A substantive theory of } \\
\text { keeping the spirit alive: the } \\
\text { spirit within children with } \\
\text { cancer and their families }\end{array}$ & $\begin{array}{l}\text { Woodgate, } \\
\text { Degner }\end{array}$ & $\begin{array}{l}2003 \\
\text { (Canada) }\end{array}$ & Longitudinal & $\begin{array}{l}\text { Children with cancer and their families focus on the need to } \\
\text { keep the spirit alive, seeking their inner essences to help them get } \\
\text { better from the disease. }\end{array}$ \\
\hline $\begin{array}{l}\text { Quality of life among } \\
\text { childhood leukemia patients }^{(8)}\end{array}$ & Hicks et al & $\begin{array}{l}2003 \\
\text { (USA) }\end{array}$ & $\begin{array}{l}\text { Descriptive } \\
\text { qualitative }\end{array}$ & $\begin{array}{l}\text { Hope, related to spiritual well-being, does not allow the disease to } \\
\text { have a lasting impact. }\end{array}$ \\
\hline $\begin{array}{l}\text { Re-signification of the } \\
\text { symbolic pain of death: } \\
\text { mental relaxation, mental } \\
\text { imagery and spirituality }{ }^{(9)}\end{array}$ & Elias & $\begin{array}{l}2003 \\
\text { (Brazil) }\end{array}$ & Analytical & $\begin{array}{l}\text { The integration of mental relaxation techniques, visualization of } \\
\text { mental images, and the elements which describe spirituality favor } \\
\text { terminal patients giving new meaning to the symbolic pain of } \\
\text { death. }\end{array}$ \\
\hline $\begin{array}{l}\text { Adventure therapy: a mental } \\
\text { health promotion strategy in } \\
\text { pediatric oncology } y^{(10)}\end{array}$ & Epstein & $\begin{array}{l}2004 \\
\text { (Canada) }\end{array}$ & $\begin{array}{l}\text { Literature } \\
\text { review }\end{array}$ & $\begin{array}{l}\text { Cancer provides opportunities for reflection and self evaluation } \\
\text { among adolescents, creating spiritual and emotional growth. }\end{array}$ \\
\hline $\begin{array}{l}\text { Human suffering: the need for } \\
\text { relationship-based research in } \\
\text { pediatric end-of-life care } \text { (11) }^{(11)}\end{array}$ & Kane et al. & $\begin{array}{l}2004 \\
\text { (USA) }\end{array}$ & $\begin{array}{l}\text { Literature } \\
\text { review }\end{array}$ & $\begin{array}{l}\text { Spiritual support is essential to alleviate the suffering of children } \\
\text { with cancer in the final stages of life and of their families, and } \\
\text { may be offered by people engaged in social networking. }\end{array}$ \\
\hline $\begin{array}{l}\text { The adolescent resilience } \\
\text { model as a guide to } \\
\text { interventions }{ }^{(12)}\end{array}$ & Haase & $\begin{array}{l}2004 \\
\text { (USA) }\end{array}$ & $\begin{array}{l}\text { Literature } \\
\text { review }\end{array}$ & $\begin{array}{l}\text { Spirituality is an important mechanism related to the way in } \\
\text { which individuals extract the meanings of the disease, frequently } \\
\text { used in the face of suffering. }\end{array}$ \\
\hline $\begin{array}{l}\text { Use of alternative and } \\
\text { complementary therapies in } \\
\text { children with cancer }{ }^{(13)}\end{array}$ & Martel et al. & $\begin{array}{l}2005 \\
\text { (Canada) }\end{array}$ & Transversal & $\begin{array}{l}\text { The use of spiritual / mental strategies is the type of alternative } \\
\text { therapy the most often reported by children with cancer. }\end{array}$ \\
\hline $\begin{array}{l}\text { Health-related quality of } \\
\text { life and enrollment in phase } \\
1 \text { trials in children with } \\
\text { incurable cancer }{ }^{(14)}\end{array}$ & $\begin{array}{l}\text { Barrera } \\
\text { et al. }\end{array}$ & $\begin{array}{l}2005 \\
\text { (Canada) }\end{array}$ & $\begin{array}{l}\text { Descriptive } \\
\text { qualitative }\end{array}$ & $\begin{array}{l}\text { Spiritual issues related to the maintenance of hope, spiritual } \\
\text { connection with God and search for meaning in life are present } \\
\text { during the fight against cancer. }\end{array}$ \\
\hline $\begin{array}{l}\text { Thematic evidence of } \\
\text { psychosocial thriving in } \\
\text { childhood cancer survivors }{ }^{(15)}\end{array}$ & $\begin{array}{l}\text { Parr } \\
\text { Ches }\end{array}$ & $\begin{array}{l}2005 \\
\text { (USA) }\end{array}$ & Analytical & $\begin{array}{l}\text { The process of psychospiritual change can essentially be of an } \\
\text { existential nature, oriented towards internal growth and a more } \\
\text { coherent understanding of the place one occupies in the world. }\end{array}$ \\
\hline $\begin{array}{l}\text { Use of complementary and } \\
\text { alternative medicine in pediatric } \\
\text { oncology in Singapore }\end{array}$ & Lim et al. & $\begin{array}{l}2006 \\
\text { (Singa- } \\
\text { pore) }\end{array}$ & Transversal & $\begin{array}{l}\text { Complementary and alternative the } \\
\text { with conventional treatment, and t } \\
\text { professionals is essential to the ma }\end{array}$ \\
\hline Palliative care in adolescent ${ }^{(17)}$ & $\begin{array}{l}\text { Schrijvers, } \\
\text { Meijnders }\end{array}$ & $\begin{array}{l}2007 \\
\text { (Belgium) }\end{array}$ & $\begin{array}{l}\text { Literature } \\
\text { review }\end{array}$ & $\begin{array}{l}\text { Spirituality is a positive factor i } \\
\text { important coping strategy. }\end{array}$ \\
\hline $\begin{array}{l}\text { Hope and spiritual well-being } \\
\text { in adolescents with cancer }{ }^{(18)}\end{array}$ & $\begin{array}{l}\text { Hendricks- } \\
\text { Ferguson }\end{array}$ & $\begin{array}{l}2008 \\
\text { (USA) }\end{array}$ & Transversal & $\begin{array}{l}\text { The level of spiritual well-being can vary among adolescents with } \\
\text { cancer during the experience with the disease, from the time of } \\
\text { diagnosis, with higher levels in the early stages of treatment. }\end{array}$ \\
\hline $\begin{array}{l}\text { Quality of life of adolescent } \\
\text { and young adult survivors of } \\
\text { childhood cancer }^{(19)}\end{array}$ & $\begin{array}{l}\text { Servitzoglou } \\
\text { et al. }\end{array}$ & $\begin{array}{l}2009 \\
(\text { Greece })\end{array}$ & Analytical & $\begin{array}{l}\text { Spiritual functioning present in the quality of life of those living } \\
\text { with childhood cancer can bring self-confidence and interest in } \\
\text { other persons, after experiencing disease }\end{array}$ \\
\hline $\begin{array}{l}\text { Children with advanced } \\
\text { cancer: responses to a spiritual } \\
\text { quality of life interview }\end{array}$ & $\begin{array}{l}\text { Kamper } \\
\text { et al. }\end{array}$ & $\begin{array}{l}2010 \\
\text { (USA) }\end{array}$ & $\begin{array}{l}\text { Descriptive } \\
\text { qualitative }\end{array}$ & $\begin{array}{l}\text { Children with cancer seek spiritual support through the } \\
\text { intermediary of prayers, with the intention of feeling normal, } \\
\text { improving their health and having protection for family members } \\
\text { and friends. }\end{array}$ \\
\hline $\begin{array}{l}\text { Pediatric palliative care in } \\
\text { childhood cancer nursing: } \\
\text { from diagnosis to cure or end } \\
\text { of life } \mathrm{fe}^{(21)}\end{array}$ & Foster et al. & $\begin{array}{l}2010 \\
\text { (USA) }\end{array}$ & $\begin{array}{l}\text { Literature } \\
\text { review }\end{array}$ & $\begin{array}{l}\text { Spiritual care includes the multidimensionality of pediatric } \\
\text { palliative care, as treatment decisions and planning of care } \\
\text { revolve around the meaning of life for children and their families. }\end{array}$ \\
\hline $\begin{array}{l}\text { Experience of an adolescent } \\
\text { living with and dying of } \\
\text { cancer }^{(22)}\end{array}$ & Flavelle & $\begin{array}{l}2011 \\
\text { (Canada) }\end{array}$ & $\begin{array}{l}\text { Clinical case } \\
\text { study }\end{array}$ & $\begin{array}{l}\text { During the trajectory of cancer, feelings of hope, search for meaning } \\
\text { and purpose in life have their foundations in religion, when the faith } \\
\text { and power of prayer were important sources of strength. }\end{array}$ \\
\hline $\begin{array}{l}\text { Complementary and alternative } \\
\text { medicine use among pediatric } \\
\text { patients with leukemia: the case } \\
\text { of Lebanon }{ }^{(23)}\end{array}$ & Naja et al. & $\begin{array}{l}2011 \\
\text { (Líbano) }\end{array}$ & Transversal & $\begin{array}{l}\text { Pediatric cancer patients make use of complementary and } \\
\text { alternative therapy, from the time of diagnosis; often without } \\
\text { the knowledge of health professionals, with prayer and spiritual } \\
\text { healing among the main therapies used. }\end{array}$ \\
\hline $\begin{array}{l}\text { A glimpse into the lives } \\
\text { of } 3 \text { children: their cancer } \\
\text { journey }{ }^{(24)}\end{array}$ & Wilson et al. & $\begin{array}{l}2011 \\
\text { (USA) }\end{array}$ & $\begin{array}{l}\text { Clinical case } \\
\text { study }\end{array}$ & $\begin{array}{l}\text { Social, psychological and spiritual aspects of children are as } \\
\text { important as their physical needs, being the spiritual questions } \\
\text { related to the fight against disease and life after death. }\end{array}$ \\
\hline $\begin{array}{l}\text { Spirituality and pediatric } \\
\text { cancer }^{(25)}\end{array}$ & Purow et al. & $\begin{array}{l}2011 \\
\text { (USA) }\end{array}$ & $\begin{array}{l}\text { Literature } \\
\text { review }\end{array}$ & $\begin{array}{l}\text { Spirituality is an important component for family members } \\
\text { dealing with the diagnosis and progression of cancer in children. }\end{array}$ \\
\hline
\end{tabular}




\section{DISCUSSION}

To receive a cancer diagnosis and go through the treatment period the disease generates, arguably, impacts the quality of life of children and adolescents $(8)$. However, the stimulus to maintain hope and spiritual connections can bring benefits to those who make use of internal energies for cure(14). Some of the strategies used to achieve a positive quality of spiritual life are linked to attitudes of the sick approaching God or a superior being $(20)$. For the better understanding of the adopted mechanisms, instruments such as Spiritual Quality of Life Questionnaire (20) and the Quality of Life Questionnaire (19) were developed, in order to make it possible for children undergoing cancer treatment and child-adolescent cancer survivors to verbalize important themes based on questions pertinent to their age ranges. The use of standardized instruments, such as the $S F$ 36-Health Survey (19), although it is geared for adults, has also been applied in child-adolescent cancer survivors.

Despite the indisputable importance of conventional treatment for cancer, coupled with the numerous conquests of technological advances in medicine, many families consider spirituality as an optional treatment modality for child-adolescent cancer, without, however, minimizing the importance of continuity in conventional therapy $(6,13,16,23)$. In order to establish the prevalence of use of complementary and alternative therapies in children with cancer and evaluate the motives and characteristics of these therapies, some studies were developed, through the application of semi-structured questionnaires, in order to understand the perceptions of families about adopting this modality of treatment $(6,13,16,23)$. Spiritual care can include the use of simple therapeutic resources, often, common to the daily lives of patients, such as music and art(25), even enabling quality of life in the dying process $(9)$.

Therefore, the issues related to spirituality may reflect how important coping strategies during the illness enable the search for meaning and purpose in the life of patients(5), in addition to influence in medical decisions and to delineate the elements of the experience of illness, from the time of diagnosis, suffering and death $(10,17-18,24)$. In this context, the Hopefulness Scale for Adolescents instrument was used to identify levels of hope in the adolescents living with cancer, and although the Spiritual Well-Being Scale is an instrument developed for adults, the survey enabled the identification of religious well-being and existential welfare of adolescents(18). Thus, spiritual thoughts can act as catalysts of inner strength that enable patients and family members to continue to live in the best possible way during the trajectory of cancer (7).
Just as what happens with hope, the spiritual perspective affects the way in which individuals extracted meanings of traumatic events, through a balanced sense of self in relation to others, reflection and inner reassessment, being seen as an effective and frequently used mechanism, in face of suffering $(10,12)$.

It is worth mentioning that in the presence of imminent death, some patients search for vital feelings and rely on the renewed sense of hope(22). Thus, the valuation of the expression of spirituality emphasizes the need for respect and recognition of the uniqueness of the mind-body-spirit relationship(21).

It is important to note that considerable transformations occur with those who have passed through the experience of cancer. The growth and strengthening of the spiritual dimension, a consequence of looking around them, leads them to prioritize happiness, provide service to others above materialism, and catalyzes the capacity for empathy and relationship with people who are experiencing the difficult experience through which they have already passed $(15,19)$.

\section{CONCLUSION}

The trajectory of cancer generates important repercussions on the spiritual dimension of children and adolescents, and the forms of expression may vary according to age and cognitive development.

The gaps highlighted the shortage of articles that deepen issues of the spiritual dimension of children and adolescents with cancer as its primary focus, in addition to the fact that most assessment instruments used in the studies were developed for adults. Therefore, more research is needed on this theme, since the totality of the care and the integrality of the human being is not restricted to a particular age, it is essential that we distinguish the values, beliefs and needs of children and adolescents from their families. It is worth mentioning that although the majority of analyzed articles have been written by nurses, this was not a Brazilian reality.

The present integrative review identified recommendations that, for the excellence of the care of children and adolescents with cancer and their families, it is necessary for the nursing staff to have the sensitivity to meet the one who for whom they provide care in his entirety. To value what is significant for the individual with discussions free of judgment, realizing stress factors associated with the experience of having cancer, and identifying how and in what form spirituality is embedded in the process, the nurse may encourage the production of care that promotes comprehensive health. 


\section{REFERENCES}

1. Brasil. Ministério da Saúde. Instituto Nacional de Câncer (INCA), Instituto Ronald Mcdonald. Diagnóstico precoce do câncer na criança e no adolescente. Rio de Janeiro: INCA; 2009.

2. Menossi MJ, Zorzo JC, Lima RA. The dialogic life-death in care delivery to adolescents with cancer. Rev Latinoam Enferm. 2012;20(1):71-82.

3. McSherry W. The principal components model: a model for advancing spirituality and spiritual care within nursing and health care practice. J Clin Nurs. 2006;15(7):905-17.

4. Nascimento LC, Oliveira FC, Moreno MF, Silva FM. Spiritual care: an essential component of the nurse practice in pediatric oncology. Acta Paul Enferm. 2010;23(3):437-40.

5. Hart D, Schneider D. Spiritual care for children with cancer. Semin Oncol Nurs. 1997;13(4):263-70.

6. Friedman T, Slayton WB, Allen LS, Pollock BH, DumontDriscoll M, Mehta P,_et al. Use of alternative therapies for children with cancer. Pediatrics. 1997;100(6):E1.

7. Woodgate RL, Degner LF. A substantive theory of keeping the spirit alive: the spirit within children with cancer and their families. J Pediatr Oncol Nurs. 2003;20(3):103-19.

8. Hicks J, Bartholomew J, Ward-Smith P, Hutto CJ. Quality of life among childhood leukemia patients. J Pediat Oncol Nurs. 2003;20(4):192-200.

9. Elias AC. Resignificação da dor simbólica da morte: relaxamento mental, imagens mentais e espiritualidade. Psicol Ciênc Prof. 2003;23(1):92-7.

10. Epstein I. Adventure therapy: a mental health promotion strategy in pediatric oncology. J Pediatr Oncol Nurs. 2004; 21(2):103-10.

11. Kane JR, Hellsten MB, Coldsmith A. Human suffering: the need for relationship-based research in pediatric end-of-life care. J Pediat Oncol Nurs. 2004;21(3):180-5.

12. Haase JE. The adolescent resilience model as a guide to interventions. J Pediat Oncol Nurs. 2004;21(5):289-99.

13. Martel D, Bussières JF, Théorêt Y, Lebel D, Kish S, Moghrabi A,_et al. Use of alternative and complementary therapies in children with cancer. Pediatr Blood Cancer. 2005;44(7):660-8.

14. Barrera M, D'Agostino N, Gammon J, Spencer L, Baruchel $\mathrm{S}$. Health-related quality of life and enrollment in phase 1 trials in children with incurable cancer. Palliat Support Care. 2005;3(3):191-6.

15. Parry C, Chesler MA. Thematic evidence of psychosocial thriving in childhood cancer survivors. Qual Health Res. 2005;15(8):1055-73.

16. Lim J, Wong M, Chan MY, Tan AM, Rajalingam V, Lim LP, et al. Use of complementary and alternative medicine in pediatric oncology in Singapore. Ann Acad Med Singapore. 2006;35(11):753-8.

17. Schrijvers D, Meijnders P. Palliative care in adolescents. Cancer Treat Rev. 2007;33(7):616-21.

18. Hendricks-Ferguson V. Hope and spiritual well-being in adolescents with cancer. West J Nurs Res. 2008;30(3):385-401.

19. Servitzoglou M, Papadatou D, Tsiantis I, Vasilatou-Kosmidis $\mathrm{H}$. Quality of life of adolescent and young adult survivors of childhood cancer. J Pediatr Nurs. 2009;24(5):415-22.

20. Kamper R, Van Cleve L, Savedra M. Children with advanced cancer: responses to a spiritual quality of life interview. J Spec Pediatr Nurs. 2010;15(4):301-6.

21. Foster TL, Lafond DA, Reggio C, Hinds PS._Pediatric palliative care in childhood cancer nursing: from diagnosis to cure or end of life. Semin Oncol Nurs. 2010;26(4):205-21.

22. Flavelle SC. Experience of an adolescent living with and dying of cancer. Arch Pediatr Adolesc Med. 2011;165(1):28-32.

23. Naja F, Alameddine M, Abboud M, Bustami D, Halaby RA. Complementary and alternative medicine use among pediatric patients with leukemia: the case of Lebanon. Integr Cancer Ther. 2011;10(1):38-46.

24. Wilson K, Mazhar W, Rojas-Cooley T, De Rosa V, Van Cleve L. A glimpse into the lives of 3 children: their cancer journey. J Pediatr Oncol Nurs. 2011;28(2):100-6.

25. Purow B, Alisanski S, Putnam G, Ruderman M. Spirituality and pediatric cancer. South Med J. 2011;104(4):299-302. 